Boston University School of Law

Scholarly Commons at Boston University School of Law

Faculty Scholarship

1977

Allocation of Artificial Hearts in the Year 2002: Minerva v. National Health Agency

George J. Annas

Follow this and additional works at: https://scholarship.law.bu.edu/faculty_scholarship

Part of the Health Law and Policy Commons 


\section{Allocation of Artificial Hearts in the Year 2002: Minerva v. National Health Agency}

George J. Annas, J.D., M.P.H.*

\section{EDITOR'S NOTE}

The rapid growth of medical technology gives rise to difficult dilemmas concerning the appropriateness of, and access to, new equipment and devices capable of maintaining life or improving its quality. Such a dilemma already exists, for example, with regard to kidney dialysis machines. In 1972, Congress amended the Social Security Act to make such machines available under Medicare to all who needed them. But almost immediately the overwhelming cost of such equipment-in the billions of dollars-made the original appropriations totally inadequate, and prompted serious questions of whether access to kidney dialysis should be made available at public expense-and, if so, to whom.

This Comment takes the reader 25 years into the future through the medium of a hypothetical U.S. Supreme Court decision** regarding a federal health agency's regulations that establish a system for allocating artificial hearts to those whose lives can be lengthened by implantation. The author assumes that a national health insurance system has been enacted and implemented, that all physicians are employees of the federal government, and that the enabling legislation has placed' broad powers in the hands of the federal government to regulate the development and allocation of scarce and expensive medical resources. The opinions of the various Supreme Court Justices reflect a broad range of legal and ethical viewpoints, and-in keeping with the difficult, indeed frightening, life-or-death issues involved-are often intensely personal in nature.

* A.B. 1967, Harvard College; J.D. 1970, Harvard Law School; M.P.H. 1972, Harvard School of Public Health; Director, Center for Law and Health Sciences, Boston University; Editor-in-Chief, Medicolegal News; Assistant Professor, Boston University School of Medicine.

A version of this Comment was originally prepared for the Boston University Program on Public Policy for Quality Health Care's November 1976 Conference on Health Care Technology and Quality of Care under the title Rationing Health Technology: Legal and Ethical Issues, copyright 1976 by George J. Annas. This Comment copyright (C) 1977 by George J. Annas and the American Journal of Law \& Medicine.

** Footnotes in this Comment are to be read as footnotes to the various hypothetical written opinions of the Supreme Court Justices. To comply with Journal style, the footnotes below are numbered consecutively. In an actual Supreme Court case, of course, each Justice's written opinion would have its own set of consecutively numbered footnotes. 


\section{SUPREME COURT OF THE UNITED STATES}

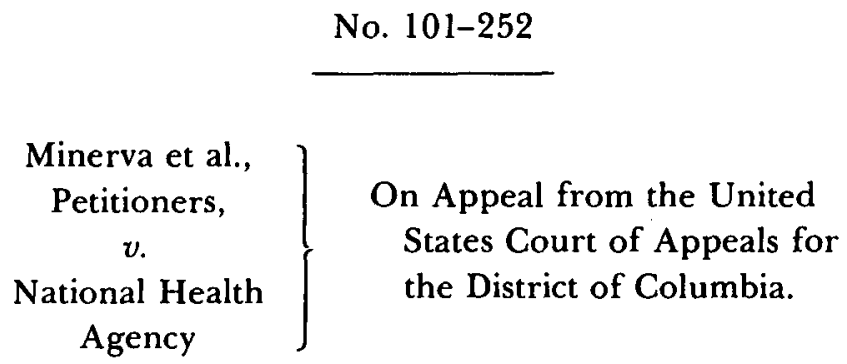

[November 20, 2002]

Synopsis

In 1998 the National Health Agency ("the Agency") promulgated regulations which provided for the allocation of artificial hearts in the United States under the authority of the National Health Insurance Act of 1982 (P.L. 97-602). The regulations prohibited the manufacture, sale, or implantation of an artificial heart without a permit from the Agency; prohibited individual purchasers from being recipients of artificial hearts without a permit from the Agency; and provided that permits to recipients be issued only by the Agency's computer, which would pick qualified applicants at random from a master list. This regulation is challenged by Dr. $P$. Minerva, a thoracic surgeon, and two of her patients, $Z$. Themis and Z. Dike. Themis did not meet the Agency's qualifications standards as he is less than fifteen years old; Dike, while meeting the standards, has not yet been chosen by the computer. The plaintiffs challenge the regulations as being a violation of their right to privacy, and challenge both the qualification criteria and the random selection procedure as being violations of their rights to equal protection and due process under the fifth amendment to the U.S. Constitution. This appeal is taken from a decision in favor of the Agency by the Court of Appeals for the District of Columbia. Minerva v. National Health Agency, 194 F.3d 28 (D.C. Cir. 2001). Additional relevant facts are set forth in the opinion of the Chief Justice.

Chief Justice Clio delivered the opinion of the Court.

When Congress passed the National Health Insurance Act it granted exceptionally broad powers to the National Health Agency ("the Agency"). One of these powers was the exclusive authority to allocate scarce and expensive medical resources. The Agency has been granted the authority to suspend and revoke medical licenses-all of which have been issued 
exclusively under federal authority since $1982 \multimap$ of individuals who violate, aid a violator, or conspire to violate the allocation regulations promulgated by the Agency. These provisions of the Act have been previously challenged and upheld by this court in Arusha v. National Health Agency, 19 U.S.2d 124 (1990). In that case, which involved an agency decision to prohibit the use of kidney dialysis machines and ordered all existing kidney dialysis clinics shut down based on a cost-benefit analysis, this court found such action permissible. Our decision was grounded on a finding of a compelling governmental interest in containing costs and properly allocating resources under the National Health Insurance Program, and a finding that no other reasonable alternative was available to the Agency with regard to this technology. The authority of the Agency to make allocation decisions and to enforce these decisions through licensing sanctions is thus no longer open to challenge.

After a decade of relative indifference in the 1970's, the implantable artificial heart, powered by a battery, was developed and widely tested in the 1980's and early 1990's. By 1996 more than 10,000 of these devices were being implanted annually in the United States at a cost of approximately $\$ 30,000$ each (in terms of 1980 U.S. dollars). The 1996 projections of the National Health Agency were that the annual demand for such hearts would reach approximately one million by the year 2010 , and that the National Health Service did not have sufficient funds, personnel, or facilities to implant and maintain such a large number of devices. For example, while the devices are serviceable, they do break down and all are equipped with a monitoring and warning system that advises the wearer when to get to an emergency ward (EW) for service and repair. Up to 20 percent of all EW visits may involve such maintenance in 20 years time. Moreover, a Social Security study found that unlimited use of this device could result in people living longer and this could have the effect of drastically increasing Social Security payments while simultaneously decreasing tax revenues.

Accordingly, the Agency decided, after more than a year of periodic public hearings, to make available annually a maximum of 20,000 artificial hearts. The Agency was statutorily established as the exclusive controller of supply in an effort to insure both adequate quality control and fairness in patient selection procedures. The allocation scheme promulgated by the Agency and challenged by the plaintiffs provides: ${ }^{1}$

121 C.F.R. 324.885 (1)-(2) (1998). The government has had similar schemes under study for more than three decades. See, e.g., Dep't of Health, Education, and Welfare, Pub. No. (NIH) 74-191, The Totally Implantable Artificial Heart: A Report of the Artificial Heart Assessment Panel of the National Heart and lung Institute (June 1973); ]. Katz \& A. M. Capron, Catastrophic Diseases: Who Decides What? 184-196 (1975); and F. Moore, Transplant: The Give and Take of Tissue Transplantation 107, 287 (1972). 
(1) To be placed on the National Waiting List for Artificial Hearts, the candidate must meet the following criteria: He or she must

(a) be more than 15 years old but less than 70 years old;

(b) be capable of living at least 10 additional years if the implant procedure is successful; and

(c) not be a chronic alcoholic or a drug addict.

(2) Individuals certified as meeting the criteria in part (1) by a physician certified by the National Health Agency as a qualified thoracic surgeon shall have their names immediately placed on the National Waiting List for Artificial Hearts. Individuals will be selected from this list at random at the rate of 400 a week. Individuals will be notified of their selection by telegram which will indicate the date and place of the implant procedure. All transportation costs will be paid by the National Health Service. Individuals shall remain on the list until they die, or until such time as they fail to meet any of the criteria set forth in part (1).

Plaintiff Minerva's initial argument is that these regulations have "no rational connection with a patient's needs and unduly [infringe] on the physician's right to practice." Doe v. Bolton, 410 U.S. 179 (1973). She argues that her patients should be permitted to purchase artificial hearts with their own funds and have her implant them without any interference from the Agency. This argument need not detain us. When the National Health Insurance Act was passed, Congress made it a national priority to provide all its citizens with unlimited access to a specified amount and type of medical care. Any other care was to be rendered at the discretion of the National Health Agency and pursuant to its regulations. So long as such regulations are consistent with the Act and are reasonable methods of rationing expensive and scarce medical resources, they will not be found by this Court to be a violation of the physician's right to practice.

The National Health Agency has permitted a private market in many types of health care-although not in any area of thoracic surgery. This is because after the publication of numerous studies in the late 1970's demonstrating a gross oversupply of surgeons, residency positions in this specialty were sharply curtailed. As a result, by 1990 the supply of surgeons in general, and thoracic surgeons in particular, was deemed to be near optimal. The supply, however, was at a point where the shifting of a significant number of surgeons out of the National Health Service would have severely restricted the ability of the Health Service to provide adequate surgical services to the population.

Accordingly, the Health Agency prohibited private surgical practice except under very restrictive conditions. This prohibition was upheld by 
the court in 1997 in American Medical Association v. National Health Agency, 28 U.S.2d 10 (1997): The basis for this decision was that failure to restrict private surgical practice would endanger the health of the members of the public who could not afford private surgical services, since the supply of surgeons and surgical services in hospitals was not adequate to permit elective procedures to be performed on a large scale without a significant decrease in the supply of surgical services to the Health Service. The same rationale, of course, applies to the present case. If a private market in artificial hearts were permitted, a significant percentage of the one million patients a year who need such hearts would purchase this procedure. These purchases could take more than half of all existing thoracic surgeons out of the Health Service, leaving the remainder of the population without sufficient services in this vital area. These effects were felt as early as 1996 when, with only 10,000 implant procedures being performed annually, the average waiting time for other thoracic surgery increased from four to six months. Justice Melpomene argues that a black market in artificial hearts will be produced by these regulations. This is sheer speculation, and in any event the potential existence of such a market should not prevent the federal government from adopting a policy it believes is right and just.

We cannot allow the avarice of a few to jeopardize the health of the many, especially in view of the fact that the many subsidized the training of all currently practicing physicians, continue to subsidize all hospital and surgical facilities, and almost completely subsidized the development of the AH1109 model of the artificial heart. The private market in health care is a fiction to which this Court will not subscribe. The physician's "right to practice medicine" properly is regulated and circumscribed by the National Health Agency for the benefit of the public. The regulations properly seek to extend the lives of as many citizens as possible-within the fiscal, personnel, and facility realities of the National Health Service.

\section{II}

Plaintiffs Themis and Dike challenge the regulations as being a denial of fifth amendment due process and equal protection of the laws. The due process argument can be disposed of easily. Plaintiffs argue that they have a right to a hearing, a right to be represented by counsel, a right to an appeal, a right to access to all of the information on file at the National Health Agency concerning each qualified candidate, and a right to challenge the qualifications or comparative qualifications of each candidate.

While the arguments put forth are interesting, they are not persuasive. The allocation scheme is not adversarial. It does not seek to pit the plaintiffs against all other candidates. Indeed, it is possible that all the candidates in a given year will be found to be qualified. The scheme is merely an exclusionary one, designed to deny the operation to those who would not 
derive a sufficient benefit from it to warrant the societal expenses involved. Moreover, the issues are not based on facts personal to the applicant, as in other cases requiring an adjudicatory hearing, but are much more in the nature of applying general policy guidelines. Davis, Administrative Law $\S 7.03$. Therefore, no procedural due process safeguards, other than the certification of the examining physician, are constitutionally required. Furthermore, such additional due process mechanisms, if utilized, could do more harm than good. By delaying the implantation process and by involving the certifying physicians in court battles, time would be lost that could more effectively be spent in screening and treating patients. All potential recipients would suffer.

The equal protection argument is stronger; but for the reasons set forth below, we reject it. The plaintiffs correctly assert that even though the federal government has not directly created the scarcity in artificial hearts, nonetheless when it attempts to regulate their distribution the government is bound by the mandates of equal protection. Under the equal protection doctrine of the United States Constitution it also "seemingly makes no difference that the threatened interest is a privilege rather than a right. Even a privilege, benefit, opportunity, or public advantage may not be granted to some but withheld from others where the basis of the classification and difference in treatment is arbitrary."2 To deny artificial hearts to a group of citizens, the federal government must demonstrate that the classification is based on reasonable grounds in light of the purpose sought to be attained by the Congress, and is not arbitrary and does not cause invidious discrimination. Plaintiffs have urged us to declare the right to an artificial heart a "fundamental interest," or to declare the qualifications for selection "suspect" so that the federal government must demonstrate a compelling state interest to uphold the regulations. We decline to construe the issues at stake so broadly. While the right to life is certainly fundamental and worthy of constitutional protection, the individual's interest in obtaining specific scarce and expensive medical devices is not. Likewise, while the criteria do establish a certain category of qualified recipients, they are drawn narrowly and with a rational relationship to a legitimate governmental purpose. This Court has been very reluctant to expand either the list of fundamental interests or of suspect classifications, and we find no necessity to do so in this case. We do note, however, that even if we concluded otherwise, we would find that the federal government

\footnotetext{
2 Van Alstyne, The Demise of the Right-Privilege Distinction in Constitutional Law, 81 HARV. L. Rev. 1439, 1454-55 (1968), citing Weiman v. Updegraff, 344 U.S. 183, 192 (1952). In Weiman this Court struck down a state loyalty oath which the Court read as not containing a scienter requirement, saying, "we need not pause to consider whether an abstract right to public employment exists. It is sufficient to say that constitutional protection does extend to the public servant whose exclusion pursuant to a statute is patently arbitrary or discriminatory."
} 
had a compelling interest in promoting the allocation scheme outlined in the regulations and that the scheme was reasonably related to this interest.

In general, this Court has been extremely reluctant to interfere with government-mandated allocation schemes. Thus, in Dandridge v. Williams, 397 U.S. 471 (1970), we upheld Maryland's AFDC program even though in setting an absolute maximum of $\$ 250$ per family it discriminated against members of larger families. Likewise, in Belle Terre $v$. Boraas, 416 U.S. 1 (1974), we found a regulation which limited the number of unrelated persons living in a household to be a valid means of controlling vehicular traffic and overcrowding. However, in Dept. of Agriculture v. Moreno, 413 U.S. 528 (1973), we struck down a food stamp regulation requiring all members of a household to be related. Even though the federal government argued that this requirement was necessary for the prevention of fraud, we could find no rational relationship between this regulation and the purpose of the statute: to feed the poor. The distinctions between these cases are worth emphasizing. In no instance in Dandridge was any family completely deprived of a fundamental requirement of life, and the issues in Belle Terre did not involve necessities of life.

The lesson from these cases is that this Court will not permit the federal government to deprive its citizens of life's necessities. It will, however, permit the allocation of resources that, while important, are not commonly thought of as necessities of life, provided that the allocation scheme is based upon a valid governmental interest, is for a legitimate purpose, is reasonable, and is not invidiously discriminatory. ${ }^{3}$ As applied to the National Health Agency, we conclude that the state cannot deprive its otherwise healthy citizens of "life's necessities" such as emergency medical services. However, when an expensive medical technology can properly be labeled a luxury, even though it does sustain life, the state need not provide it to all citizens.

We find that an artificial heart is no more necessary to an individual than a castle or dinner at Maxim's. Individuals need food, shelter, and medical care-but they may not convert the shield against starvation, exposure, and sickness that the federal government must provide into a sword with which to extract luxuries that society cannot afford. Nature, not the federal government, takes the lives of those who are unsuccessful in the artificial heart lottery. The purposes of maximizing lives within resource constraints and of preventing the destruction of the National Health Service are valid and the rationing scheme adopted is reasonably related to accomplishing these purposes.

We find therefore that the current regulations are not constitutionally ${ }^{3}$ (1969). 
objectionable. There seem to be only two ways to avoid rationing: universal treatment or universal nontreatment. The first option is simply not feasible. Congress has refused to vote the more than $\$ 30$ billion (in terms of 1980 dollars) in funds annually required for universal treatment, and through this Congressional refusal the taxpayers have indicated that they would rather retain the money necessary for this program for their own discretionary use than to pay for the tax increase necessary to finance universal treatment. The second option, universal nontreatment, makes sense only if it is in fact impossible to make non-arbitrary distinctions among competing applicants, or impossible to devise an equitable arbitrary rationing process. We find neither to be the case, and therefore conclude that the federal government has a right to set up a rationing scheme. ${ }^{4}$

Plaintiffs have raised the following objections to the "Criteria for Placement on the National Waiting List for Artificial Hearts": (1) by specifically denying treatment to most applicants, the regulations cheapen human life and undermine society's belief in the equality of life; (2) the criteria are not medical at all, but are based on "social worth," a criterion specifically denounced in the Conference Committee Report on P.L. 97602 , and a criterion which also undermines our belief in the equality of life; and (3) the artificial heart lottery provisions are unnecessarily imprecise and lead to squandering of the federal government's resources since they fail to take into account the relative life expectancy of one applicant versus another or the degree to which one applicant desires the implantation as opposed to another. Thus, the scheme inherently is inequitable and irrational, and only significant modifications in it would make it constitutionally acceptable. $^{3}$

We shall deal with these objections in the order in which they were raised. The first is a general argument against any attempt to ration scarce medical resources and we reject it outright. By attempting to save as many

${ }^{4}$ Cf. Ross v. Moffitt, 417 U.S. 600 (1974) (equal protection does not require absolute equality, only freedom from unreasonable distinctions).

s The plaintiffs suggest that there may also be an unconstitutional delegation of Congressional authority to the National Health Agency in permitting them to establish an allocation scheme based on arguably arbitrary criteria devised without Congressional guidance or standards. While this is an interesting argument, it is one we have consistently rejected since 1935, the date of the last cases holding a Congressional delegation of authority improper. Panama Refining Co. v. Ryan, 293 U.S. 388, and A.L.A. Schechter Poultry Corp. v. United States, 295 U.S. 495. As we stated in 1940, and consistently thereafter, "Delegation by Congress has long been recognized as necessary in order that the exertion of legislative powers does not become a futility." Sunshine Anthracite Coal Co. v. Adkins, 310 U.S. 381. While "an unnecessarily broad delegation could combine with encroachment on other protected constitutional interests to create an unconstitutional result" we will not hold any responsible delegation of authority unconstitutional. Davis, Administrative Law $\$ 2.01$. 
lives as possible, society does not cheapen human life. On the contrary, it attempts to the best of its ability to protect and prolong life. The fact that all will not benefit from this new technology does not mean that no one should. ${ }^{6}$ All citizens cannot live within ten miles of an emergency ward equipped to deal in the most efficient way with cardiac arrests. This does not mean we must close these facilities. It only means that they should not be permitted to discriminate arbitrarily among patients who present themselves for treatment.

Themis's argument focuses on the age limitations utilized. We find, however, that they are reasonably related to the purposes of the regulation and, therefore, are proper. The fifteen year age cut-off reflects both the age of majority (lowered from eighteen to fifteen in 1990) and thus of consent to medical procedures, and the fact that the thoracic cavity will not, in general, be large enough to house the standard AH1109 model of the artificial heart currently in use. The informed consent issue and the rationale for not implanting the heart in anyone incapable of giving informed consent is sufficiently dealt with in the concurring opinion of our sister Justice Melpomene.

Parenthetically, we note that the seventy year age limit reflects the overall judgment of the Agency that individuals beyond this age are so likely to be afflicted with other conditions that could prove fatal that it makes more sense simply to eliminate them entirely from the process rather than to spend the resources to screen them. While one may disagree with these reasons, Themis has failed to demonstrate to the satisfaction of the court that these age limitations are so arbitrary as to erode our belief in the equality of human life.

The second objection is more serious. Social worth criteria are to be condemned because they are so imprecise as to maximize the probabilities of arbitrary decisions based on personal biases of the decision-maker. We believe, however, that the criteria formulated by the Agency are essentially medical in nature and as such are capable of precise and nonarbitrary application by qualified thoracic surgeons. All of the screening surgeons must meet the strict requirements for certification by the Agency, and we must assume that they will honestly and fairly perform their functions under the regulations. Withrow v. Larkin, 421 U.S. 35 (1975). Moreover, the criteria are reasonable in that they preclude from allocation those who will gain only marginally from the implant, and thus help to maximize society's benefits as compared with the costs of this program. Age, prognosis with implant, drug addiction, and alcoholism are all characteristics that are readily ascertainable by a qualified physician and all can be considered strictly medical criteria.

\footnotetext{
As our predecessor Oliver Wendell Holmes so aptly stated, "The law does all that is needed when it does all it can. ..." Buck v. Bell, 274 U.S. 200, 208.(1927).
} 
The third argument is somewhat troublesome, but inasmuch as the plaintiff Dike has not suggested any way in which desire can be quantified and measured on a comparative basis, we need not deal with it.

Additional support for the type of rationing scheme chosen by the Agency is found in law and custom. One 1842 case involved an American ship which was near Newfoundland, en route from Liverpool to Philadelphia, when it struck an iceberg. The crew and half the passengers escaped on two overly-filled lifeboats. One contained 41 individuals and after about 24 hours it became clear that unless some went overboard, all would perish. The first mate had his crew ( 8 in number) throw out 14 passengers using the rule "not to part man and wife, and not to throw over any women." At the trial of one of the seamen for homicide, the court instructed the jury that under extraordinary circumstances the "law of necessity" 7 may justify taking a life, but that in choosing who shall live and who shall perish "there should be consultation and some mode of selection fixed, by which those in equal relations may have equal chance for life ... for ourselves we can conceive of no mode so consonant both to humanity and justice [as casting lots]." 8

Not only was a lottery approved, but the court also concluded that the first mate and as many of the crew as were necessary to run the boat did not have to take part. Thus, the court sanctioned the exclusion, based on specified criteria, of certain members of society from a lottery scheme. While this case involved choosing individuals to die, not to live, as is the case in allocating artificial hearts, the same standard applies in the latter case. The traditional rule of the sea when a ship is sinking has always been women and children first. This principle seems to rest on the notions that women are necessary for the survival of the species, and that children have more years left to contribute to society than adults. This traditional principle and the lifeboat case both sanction "social worth" criteria under certain extreme cases, the arguments of our sister Justice Urania nothwithstanding. ${ }^{9}$

The decision of the Court of Appeals of the District of Columbia is accordingly

Affirmed.

\footnotetext{
${ }^{7}$ For a brilliant discussion of this concept, see Fuller, The Case of the Speluncean Explorers, 62 Harv. L. Rev. 616 (1949).

${ }^{8}$ United States v. Holmes, 26 F. Cases 360, 367 (Cir. Ct. Pa. 1842). See also Holmes v. N.Y. City Housing Authority, 398 F.2d 262 (2d Cir. 1968) (the court indicated it would approve an allocation scheme in public housing based on a first-come, first-serve basis with certain specified exceptions).

'See Dukeminier and Sanders, Legal Problems in Allocation of Scarce Medical Resources: The Artificial Kidney, 127 ARCh. IntERn. MEd. 1133, 1134 (1971).
} 
Calliope, Terpsichore, and Polyhymnia, JJ. concur in The Chief JUSTICE'S opinion.

Justice Melpomene, concurring in the result.

While I join my sisters in upholding these regulations as valid and constitutional exercises of authority by the National Health Agency, I feel compelled to pen a separate opinion. In my view, there should be no allocation scheme whatsoever mandated by the federal government: artificial hearts simply should be outlawed in this country. I come to this conclusion even though I myself have such a device pumping blood through my arteries. It never gives me peace. When I am alone in my bed at night I hear it. It reminds me both of my mortality and of my humanness-but it taunts me with the notion that I am no longer fully human, and that I am already partially dead.

Furthermore, how can one give informed consent to receive such a device? I did (or so I thought), but when faced with death, people are likely to consent to anything. We all know this. It is ancient history that Dr. Christiaan Barnard noted of the first recipient of a human heart that consent to this procedure was not heroic but to be expected:10

He was ready to accept it because he was at the end of the line. What else was there to say? . . . Since then many people have said it was very brave of Mr. Washkansky to accept the heart transplant. They really mean it would be brave for them to accept a heart transplant, not Washkansky. For a dying man, it is not a difficult decision because he knows he is at the end. If a lion chases you to the bank of a river filled with crocodiles, you will leap into the water convinced you have a chance to swim to the other side. But you would never accept such odds if there was no lion.

Likewise, Dr. Denton A. Cooley wrote of the first human ever to receive an implanted artificial heart: "He was a drowning man. A drowning man can't be too particular what he's going to use as a possible life preserver. It was a desperate thing and he knew it." 11

Currently, implants are no longer experimental, and the situations of patients are no longer so "desperate." Nevertheless, it is my experience that a significant number of candidates feel they must have an artificial heart, and will do almost anything to gain access to one. ${ }^{12}$ This impulse may be based solely on the irrational desire to live forever.

${ }^{10}$ C. Barnard \& C. B. Pepper, One Life 311 (1969).

11 Quoted in J. Thorwald, The Patients 402 (1972).

12 In this regard it is my view that while a deductible of one year's income would help to measure "desire," it would not significantly reduce the number of applicants since money becomes less meaningful as the time available to spend it decreases. 
It is my view that any attempt to ration artificial hearts, even one so carefully drawn as the regulations under consideration, will fail to prevent significant black markets in such hearts; will encourage surgeons in the National Health Service (who consider themselves grossly underpaid) to operate in this market; and will encourage patients to attempt to bribe health officials and physicians, and to commit other crimes in an effort to obtain an artificial heart.

For these reasons-because the artificial heart is fundamentally inhuman and inhumane, because informed consent can never be obtained, and because allocation will lead to many undesirable side effects in society-I would outlaw these devices altogether. Nevertheless, since I believe this is properly a Congressional decision, I vote to uphold regulations that at least attempt to limit their distribution.

Justice Urania, with whom Justice Thalia and Justice Erato join, dissenting.

The Supreme Court today approves an allocation scheme that is inherently inequitable and unjust, that undermines society's view of the sacredness and equality of human life, and that makes social worth the standard for longevity in our society. The majority asserts that the allocation scheme reflects the application of rational and exact medical criteria. In fact, however, the regulations permit individual physicians to make arbitrary decisions based solely on their own views of social worth. Since physicians in general, and thoracic surgeons in particular, are likely to have a white upper-middle class male bias in this area, ${ }^{13}$ such a classification scheme inherently is violative of the equal protection mandate implicit in the fifth amendment of the U.S. Constitution.

\section{I}

The true character of the regulations may be seen in a recent study of the persons who were accepted and those who were rejected for places on the National Waiting List for Artificial Hearts for the year 2000 (the only full year for which statistics are available). ${ }^{14}$ In that year more than two million persons applied for the Waiting List. Of that number, one million, or fifty percent, were rejected. Of these, more than ninety percent were rejected on the basis of criteria (b) (incapable of ten additional years of life), or criteria (c) (chronic alcoholism or drug addiction). The statistics also indicate that at least seventy percent of each of the following categories of individuals were rejected:

${ }^{13}$ The plaintiff Minerva is one of the few exceptions to this rule.

${ }^{14}$ Glantz, Patient Selection for Artificial Hearts: The First Year, 28 AM. J. LAW \& MEd. 232 (2001). 


$\begin{array}{ll}\text { I.Q. lower than 80: } & 98 \% \\ \text { History of mental illness: } & 80 \% \\ \text { Criminal record: } & 75 \% \\ \text { Indigency: } & 80 \% \\ \text { Unemployed: } & 70 \%\end{array}$

The generality of the statistics does not permit further breakdown into more specific income level, I.Q., or type of mental illness. Nonetheless, I submit that these figures are sufficient to warrant the conclusion that the scheme mandated by the regulations discriminates invidiously and unconstitutionally against the mentally deficient, the mentally ill, those with prior criminal records, the poor, and the unemployed. While the regulations, as written, are difficult to attack, they are clearly not the criteria that surgeons have actually been using to select patients. There is no rational connection between such invidious discrimination and the state's purpose; thus, the regulations must fail a constitutional test. While the majority concludes that the classification established by these regulations should not be considered "suspect," these figures clearly indicate not only that it should, but that it is. Accordingly, the state should be required to demonstrate a "compelling interest" to permit these regulations to withstand an equal protection challenge. Whether the interest in maintaining the viability of the medical care delivery system is compelling or not depends in large part on one's view of its credibility. In my view the government has failed to demonstrate adequately that a less restrictive allocation system would lead to a total breakdown of the National Health Service. Until such evidence is forthcoming, I would rule that the compelling interest test has not been met, and therefore find the regulations constitutionally deficient.

In addition, the legislative history indicates that Congress intended that only objective medical criteria be permitted to enter the decisionmaking process. There was testimony, for example, concerning some of the initial methods used to screen patients for kidney dialysis forty years ago. One lay member of a screening committee in Seattle testified that: "The choices were hard ... I remember voting against a young woman who was a known prostitute. I found I couldn't vote for her, rather than another candidate, a young wife and mother. I also voted against a young man who, until he learned he had renal failure, had been a ne'er-do-well, a real playboy. He promised to reform his character, go back to school, and so on, if only he were selected for treatment. But I felt I'd lived long enough to know that a person like that won't really do what he was promising at the time." ${ }^{15}$ All members of the Conference Committee found these types of social worth judgments disgusting. In their final report to Congress they

\footnotetext{
${ }^{15}$ Also quoted in R. Fox and J. Swazey, The Courage to Fall 246 (1974).
} 
quoted the following language from a study of the Seattle committee of which this woman was a member: ${ }^{16}$

The descriptions of how this committee makes its decisions . . . are numbing accounts of how close to the surface lie the prejudices and mindless cliches that pollute the committee's deliberations. . . . What is meant by 'public service,' a phrase so difficult to define in a pluralistic society? Were the persons who got themselves jailed in the South while working for civil rights doing a 'public service'? What about working for the Antivivisection League? Why should a Sunday-school teacher be saved rather than Madalyn Murray? The magazines paint a disturbing picture of the bourgeoisie, of the Seattle committee measuring persons in accordance with its own middle-class values. This rules out creative nonconformists, who rub the bourgeoisie so much the wrong way but who historically have contributed so much to the making of America. The Pacific Northwest is no place for a Henry David Thoreau with bad kidneys.

The regulations are so loosely drawn, especially subsections (b) and (c), that they permit physicians to exercise completely unbridled discretion in making their choices, and permit them to make these choices not on the basis of fixed medical criteria, but on the basis of their own, sometimes warped, views of social worth. The results of the study support the conclusion that this is precisely what has been occurring. It is apparent that physicians are basing their survival estimates on such things as "cooperativeness," "rehabilitation potential," "self-esteem," "low intelligence," "impulsive, irresponsible behavior," "self-destructive wishes," "difficulty relating to authority figures," etc. A demonstrated "connection between the favored traits severally considered and ability to survive" 17 should be demanded if such criteria are to continue in use. No such connection has been demonstrated. Accordingly, the regulations should be struck down.

II

The Agency may have convinced the majority that its age limitation is reasonable, but it has not convinced me. A youth of twelve or thirteen, such as plaintiff Themis, may have a body capable of receiving the artificial heart, and should not arbitrarily be denied it simply because most other children his or her age could not be fitted with the AH1109. Likewise, is it reasonable to reject a seventy-one-year-old applicant with a life expectancy

\footnotetext{
${ }^{10}$ Sanders and Dukeminier, Medical Advance and Legal Lag: Hemodialysis and Kidney Transplantation, 15 U.C.L.A. L. REv. 357 (1968).

17 Note, Patient Selection for Artificial and Transplanted Organs, 82 HARv. L. Rev. 1322, 1339 (1969).
} 
of twenty years, while accepting a sixty-nine-year-old with a life expectancy of ten years? Such an allocation scheme is de facto irrational. Since it could be much more fairly drawn, it cannot stand constitutional challenge. I would much prefer to have simply a first-come, first-serve scheme, than to set such patently arbitrary criteria. While the first-come, first-serve system would also discriminate arbitrarily, such discrimination would be more in the nature of "acts of God" rather than explicit acts of Government, and thus would not serve to cheapen our views of human life and the equality of man. ${ }^{18}$

\section{III}

Moreover, to characterize the artificial heart as a "luxury"-which the majority does-is playing with words. Today's luxury is tomorrow's necessity. We have witnessed the "heroic" or "extraordinary" treatments of the 1970 's and '80's. Today they are commonplace in our hospitals. Artificial hearts are prolonging lives. They could prolong far more lives both now and in the future if more resources were allocated to this critical field. When, in ten or fifteen years, all the other civilized nations of the world routinely implant such devices in their citizens, will the majority change its mind? Will artificial hearts then become "natural" or at least necessary for life? If so, why must we sacrifice the present generation for the next?

\section{IV}

The allocation scheme is a threat to our values and an insult to our intelligence. We need not be guided in our decision by the unwritten rules of sailors who prowled the sea in their sail-drawn ships almost two centuries ago. How much better to learn from the more advanced planets with whom we have recently established contact. On Zeno, for example, all are eligible for artificial organs-but must make the election by their twenty-fifth birthday and accept permanent sterility as the price. In this way, they both lengthen life and control total population size (and thus the cost of the program). ${ }^{19}$ While I do not propose that we accept such an alternative without study or legislative mandate, I do reject the current scheme and the majority's endorsement of it.

Justice Thalia, dissenting.

While I join with my sister Urania in her dissent, I would argue further that her analysis leads to an additional and inescapable conclusion: the

${ }^{18}$ See, e.g., Childress, Who Shall Live When Not All Can Live?, 53 Soundings 339, 347-53 (1970). See generally G. B. Shaw, The Doctor's Dilemma (1913).

${ }^{19}$ Communication from Zeno II Tracker Station, NASA Classified Document 2119652 (level of classification is classified) (quoted with permission of the Director). 
regulations violate a candidate's right to due process. It is apparent that no matter what criteria are utilized, fairness is enhanced when there is more than one decision maker. It is inappropriate and unfair to expect a patient to dispute the findings of the examining physician to the physician himself. A procedure requiring the concurrence of two of a board of three physicians would be much fairer and presumably would lead to much more consistent and accurate decision-making. ${ }^{20}$ In addition, if the type of criteria as specified in the regulations are to be applied, and "survivability" defined as I believe my sister Justice Urania accurately indicates it is presently defined, then many more due process protections than currently exist are mandated by the U.S. Constitution. Contrary to the majority's view, the types of facts at issue in the screening process are extremely personal, and ones that are unique to the candidate. Due process, therefore, requires that the candidate be given a full adjudicatory hearing upon request. Davis, Administrative Law $\S 7.03$.

Additional safeguards are also necessary. The patient's life is at stake, and Congress has mandated a system that excludes social worth from consideration so that the fundamental belief of our society in the equality of human life is not destroyed. To insure that each potential patient has a fair opportunity of being included in the National Waiting List for Artificial Hearts it is essential that at the minimum he or she be permitted (1) to examine in advance all records in the hands of the decision-maker; (2) to have an opportunity to refute their accuracy and to supplement them; (3) to have an opportunity to call and cross-examine any individual who has presented information that might disqualify the applicant from consideration; (4) to have a record of the basis of the decision; and (5) to have an opportunity to appeal the decision to an appeals board. Unless these minimal procedural safeguards are provided (and I would also favor mandatory representation by counsel upon request, but would not require it constitutionally), it is my opinion that these regulations are constitutionally deficient and must be struck down by this court. ${ }^{21}$

${ }^{20}$ Cf. McGautha v. California, 402 U.S. 183, 196 (1971), in which U.S. Supreme Court rejected the argument that "to leave a jury completely at large to impose or withhold the death penalty as it sees fit is fundamentally lawless and therefore violates the basic command of the fourteenth amendment that no state shall deprive a person of his life without due process of law." The Court found that there was no offense against the Constitution, especially in light of "the present limitations on human knowledge" in drafting standards.

${ }^{21}$ It is worth noting that the scheme does not demand that patients be compared with one another, but only that they themselves meet certain criteria. Thus, there is no real need or incentive for patients to challenge the selection of other patients (although increases in the number of patients in the pool will decrease their individual odds of being chosen for an artificial heart). This, and the fact that it could delay individual choices for years, mandate that patient-applicants not be permitted to challenge other patients, to cross-examine their physicians and other witnesses, or to obtain injunctions against their selection. In denying applicants these rights, the Agency acted properly and wisely. 
Justice EuTERPE, dissenting.

I find the arguments of my colleagues all very interesting but, with the exception of Justice Melpomene, irrelevant. Have we progressed so much in this country that we have lost sight of our purpose as a nation? The unsubstantiated communications from Zeno notwithstanding, surely no one in their right mind will argue that we can make our citizens immortal. Even if we can produce an artificial heart that will last forever, the other tissues and organs will continue to deteriorate. While reading is not currently in fashion in our society, some will recall Gulliver's Travels and Swift's description of the Struldbrugs, creatures who did achieve immortality, but whose minds and bodies suffered from the decay of old age nonetheless: ${ }^{22}$

At ninety they lose their teeth and hair; they have at that age no distinction of taste, but eat and drink whatever they can get, without relish or appetite. The diseases they were subject to still continue without increasing or diminishing. In talking, they forget the common appellation of things and the names of persons, even of those who are their nearest and dearest friends and relations. For the same reason, they never can amuse themselves with reading, because their memory will not serve to carry them from the beginning of a sentence to the end; and by this defect, they are deprived of the only entertainment whereof they might otherwise be capable. ...

They are despised and hated. ...

They were the most mortifying sight I ever beheld.... Besides the usual deformities in extreme old age, they acquired an additional ghastliness in proportion to their number of years, which is not to be described. . . .

The energies of the National Health Agency should be directed toward the young and the middle-aged and toward making life more enjoyable and richer. It should not be directed toward prolonging the agony of death and the miseries of old age. If we are unwilling as a society to pay for the implantation of an artificial heart in each of our citizens who can reasonably benefit medically from it, then we should have the courage to adopt a rule which says that no one shall have such a device implanted. Such a rule promotes equality and fairness. It is also an attempt to allocate resources toward medical and health measures that make our lives worth living, rather than ones that prolong lives that are not worth living. I would rather deprive all of the aid of the artificial heart, as Conrad's Lord Jim and the rest of the crew deserted the passengers of the Patna, than to arbitrarily choose who shall live, as the first mate did in the lifeboat case summarized by the Chief Justice.

${ }^{22}$ Swift, Gulliver's Travels. 
Even if one were determined to implant artificial hearts in some, surely the market system is a better allocator of 20,000 hearts a year than the administratively clumsy and somewhat arbitrary scheme envisioned in the regulations. While ability to pay is itself somewhat of a social worth criterion, when coupled with a strong desire to have an implant and a willing physician, I believe it proper for deciding who will receive a medical device which is of dubious value to either the individual or society. ${ }^{23}$ It might also be appropriate to initiate a "distinguished citizen" award, the recipients being individuals of tremendous importance to our society whose lives should be prolonged for the good of us all without respect to their financial ability or even their desire for an implant.

I would finally note that I do not think it purely a coincidence that all five Justices in the majority are recipients of artificial hearts, while none of the four in the minority applied for one either before or after the regulations under question went into effect. While the decision on disqualifying oneself because of a conflict of interest or bias in a particular case is for the individual Justice, I cannot help but note that the decision would have been unanimously decided against these regulations had these Justices taken the step of disqualifying themselves from hearing this case.

2s While no real market system now exists in health care, of course, since the government owns all the means of production and most health care professionals are government employees, this does not preclude the existence of a market for some medical devices, just as there remains the existence of a market for some drugs, such as marijuana and heroin. 